\title{
Frame Device
}

National Cancer Institute

\section{Source}

National Cancer Institute. Frame Device. NCI Thesaurus. Code C49963.

A structure designed to support or contain an object. 